\title{
Disaster Mitigation Based on Local Wisdom in Shifting Cultivators Communities
}

\author{
JAMALUDDIN HOS ${ }^{1}$, SARPIN ${ }^{1}$, SUHARTY ROSLAN ${ }^{1}$, RATNA SUPIYAH ${ }^{1}$, HASNIAH $^{2}$ \\ ${ }^{1}$ Sociology Department, Faculty of Social and Political Sciences, University of Halu Oleo \\ ${ }^{2}$ Anthropology Department, Faculty of Cultural Sciences, University of Halu Oleo \\ Jl. H.E.A. Mokodompit Kendari, Sulawesi Tenggara
}

INDONESIA

\begin{abstract}
The Tolaki tribe, which is a native who inhabits the mainland areas of Southeast Sulawesi Province, some still manage their lives through traditional natural resource management. Strong traditions, including preserving the environment and forests in the Tolaki ethnic group, are always maintained. This study was directed to find out and examine the local wisdom of the Tolaki people in moving farming activities (monda'u) related to disaster mitigation, especially natural disasters of floods, landslides, and fires. The research approach used is qualitative, where the primary data collection techniques are observation and in-depth interviews. The results showed much local wisdom in an institution that has been maintained to oversee forest support and sustainability. This indicates that in monda'u activities, Tolaki people have long provided education avoiding natural disasters for generations. Norms regarding the location of the field location, the right time to farm, the rules and ordinances of the opening, burning, and clearing of land in the monda' $u$ tradition are loaded with mitigation against floods' natural disasters, landslides, and fires. This local wisdom can be integrated into modern agricultural systems to minimize natural disasters.
\end{abstract}

Key-Words: - Environmental Adaptation, Disaster Mitigation, Indigenous Peoples, Shifting Cultivation, Local Wisdom, Floods, Landslides

Received: November 29, 2020. Revised: March 22, 2021. Accepted: March 31, 2021. Published: April 12, 2021.

\section{Introduction}

A high level of disaster insanity in Indonesia is common knowledge. The disaster court's story is influenced by Indonesia's geographical position, surrounded by the world's tectonic plates. The geographical position is at the confluence of earthquake-prone tectonic plates [1]. Besides, Indonesia is also a route to the pacific ring of fire, a series of active volcanoes worldwide [2]. These geographical conditions and positions undoubtedly increase the need for people living around this ring of fire area to have high alertness.

Disaster mitigation is necessary to minimize disaster victims through anticipation and effective disaster management [3], [4]. Mitigation is an effort taken to eliminate or at least minimize harm and loss. Thus, disaster mitigation covers all human efforts and activities to protect from anticipation before the disaster, and evaluating disaster hazards to disaster management [5]. Disaster management can be in the form of rescue, rehabilitation, and relocation of disaster victims. Disaster mitigation can also be said as efforts and activities taken to reduce and minimize the consequences of disasters, which include preparedness, vigilance, and various capabilities to overcome them [6].

Historically, Indonesian has had much experience with natural disasters. Experience of disasters encourages individual and social learning to bring about disaster-related knowledge [7]. Indonesia's geological and geomorphological conditions at the ocean plate's meeting impact the frequent natural disasters in earthquakes and tsunamis. Similarly, many volcanoes have recorded many eruptions that caused many casualties [8]. Often natural disasters occur in various Indonesia; they have provided a lot of experience and knowledge about disasters passed down to each generation [9]. Local people in Indonesia generally have local knowledge and wisdom on natural disasters' symptoms and mitigate disasters.

Knowledge and wisdom of local culture in dealing with natural disasters are obtained from various experiences interacting with its ecosystem [10], [11]. Local wisdom is proven to maintain community balance, live harmoniously, durable, and sustainably [12]. Along with the development and progress achieved due to the modernization process in various aspects of life, it tends to deny local wisdom and indigenous peoples' social wealth. Developmentalism 
does make traditionalism at odds with modernization. All traditions, including cultural richness and local knowledge, are considered uns adaptive, even contrary to the principles of progress and development [13]. Today, there is a growing desire to learn from the ancients' local wisdom or philosophy that has been tested by time [11], [14].

Lately, in a disaster, Indonesia has insufficient readiness to take careful countermeasures in general. This is because of the extinction of a disaster early detection system for public access. Simultaneously, first detection systems against disasters are essential to minimize disasters' risk [15]. The community is not trained to deal with disasters, even though it has happened many times. In the event of a disaster, in general, the victim community depends heavily on the government response, which is sometimes also unplanned. Re-exploring local wisdom on disaster mitigation is essential to further serve as the basis for capacity building of the community in anticipating and handling disasters independently without depending on the government.

When excavated and further reviewed, the local people's traditions and cultural values in Indonesia have been a guideline for centuries. There is much cultural wisdom about disaster mitigation [2]. Disaster mitigation is reflected in soil, irrigation system, forest processing, and cooperation system [16], [17]. For every indigenous people in Indonesia, there is a disaster mitigation system passed down through generations.

Local wisdom is local knowledge that comes from the community's culture and has a connection with nature for an extended period. Local knowledge grows from the process of the adaptation of citizens to local ecological systems [18]. Local wisdom is dynamic and always open, with the addition of new knowledge. Local wisdom plays a vital role in preventing and reducing disasters' risk [19]. Local wisdom has established adaptive behavior towards the environment that has contributed positively to the community in dealing with the coming disaster [1]. In general, traditional people can live in harmony with the environment to establish a cultural value system in sustainable natural resource utilization. The values in traditional institutions such as monda'u can be combined with modern information technology to monitor land deformation and disaster prevention, especially in mining areas that are now overgrowing [20].

Tolaki ethnic communities, especially in North Konawe County's Asera District, are mainly livelihoods even though they are considered 'primitive' [21]. This farm activity is called monda'u, processing land fields ranging from land clearing to crop storage.
In monda'u activities, the Tolaki people have long provided education avoiding natural disasters for generations. This is the focus of this research, namely digging and reviewing the Tolaki people's wisdom in moving farming activities (monda' $u$ ) related to disaster mitigation.

\section{Research Methods}

This research was conducted in the Asera District of North Konawe Regency, Southeast Sulawesi Province, Indonesia. The research used a qualitative approach with data collection techniques through observation and in-depth interviews. The study subjects were the moving farms' actors who were still and had been doing farming activities. The number of informants were purposively chosen in snowball sampling until the information saturated. The author has conducted in-depth interviews with eleven informants consist of moving farmers and local indigenous peoples.

Observations are made on phenomena that appear to be related to migrating farms that include the selection and determination of the location of fields, felling of trees, burning of logging results to the harvesting of fields. Furthermore, in-depth interviews were conducted to explore the meaning and motivation of the field's actions behind the observed phenomenon. Interviews are shown in the fields and at the respondent's house alternately and repeatedly to obtain accurate and complete information. Interviews are conducted in an informal, casual, and intimate setting between researchers and informants.

Data collection and processing are conducted together, especially primary data obtained from observation and in-depth interviews. After receiving the data, they were grouped to distinguish, sort, and select information and data from various sources, as well as for unproblematic analysis. The data were analyzed through interpretative understanding, which means that the research interprets the data and facts related to disaster mitigation.

\section{Results and Discussions 3.1 Tolaki Ethnic Cultivation System}

Asera sub-district is one of the sub-districts in the North Konawe Regency of Southeast Sulawesi province, Indonesia. Most residents of the Asera subdistrict have livelihoods as farming. Farming families have characteristics when compared to other families in general. They rely on local experience and knowledge, and cultural values in conducting farming activities [22]. Farming activities (monda'u) live by traveling 5 - 10 kilometers from their village or home.

Soil processing for a farming activity is carried out movingly at locations that are considered fertile and 
can produce expected production. In addition to engaging family members, the processing of farmland usually gets helped from neighbors who are nearby in the first place. [23]. Due to moving around culture, the former farm activity location is overgrown along with trees and shrubs called anahoma. This former farmland forest area is usually a former processed area of several farms that still come from one large family (relatives).

Under the provisions of Tolaki's customary law, the anahoma can be re-worked by the concerned or grandchildren after nine years of abandonment. Nine years are considered sufficient to restore fertility and land resilience, as farming intensifies land recovery [24]. The terms of the former farmland area's reprocessing period have begun to be abandoned as the farmland narrows. The narrowing of the farmland is subject to increase the number of inhabitants resulting from birth and in-house migration. It is also because some forest areas have changed ownership status under customary law (right to request) to request under national law.

The shifting farming system established a distinctive land ownership concept. All former farmland area (anahoma), according to customary law, is controlled or owned by one family [25]. The scopes of anahoma include swamps where sago trees grow, areas where cows or buffalo are escaping, parts of river trunks and marshes where fish catch, land location full of plants, and ancestral landgraves. The family determines the ownership of the property by working directly or passing the property down over generations.

Like other Tolaki peoples, people living in Asera Sub-district still maintain the farming system as their livelihood system. Farming is done with land clearing in hereditary tradition. The moving farm (Tolaki: Monda' $u$ ) has system of values and norms that watch the forest's support and sustainability [26]. Monda'u activity is a whole farm activity that starts from a land clearing in forest areas to harvest barns' storage activities.

The results showed that monda' $u$ 's overall activities were processed in eleven stages as follows:

- Monggiikii ando'olo or choosing the location of the farmland.

- Perform the pre-Monda'u ritual ceremony (mohoto $o$ wuta) for the farming effort to succeed.

- Do the logging of small trees, cut down the roots and others (mosalei).

- Do the logging of large trees (mombodoi or monduehi).

- Do the burning of logging (huтипи).

- Do the cleaning of the remains of burning (mo'enggai).

- Making fences (mewala).
- Planting land with rice (motasu).

- Weeding or cleaning grass that grows in between plants and keeping plants (mosaira and mete'ia).

- Harvesting produces (mosawi).

- Putting the harvest into the barn (molonggo).

Opening farmland begins with the selection of locations or mongiikii ando'olo. The land area is chosen based on the topography, land that is fertile and flat soil. In general, people open ground as 0.5 hectares to one hectare. Limited land clearing of up to one hectare can overcome forest ecosystems [27]. After the selection of land location, the next activity is the clearing of farmland. This land clearing activity is in the dry season in mosalei, logging (mombodoi or monduehi), and burning (huтипu). The clearing land process is not just cutting down and burning trees that can lead to deforestation [28] but carried out with a strict set of customary norms to avoid fragmentation and degradation of forest functions.

The next stage in a row is the activity of harvesting (mewala), planting (motasu), treatment of crops (mosaira), and supervision of fields (meteia), harvesting (mosowi), and finally inserting the harvest into the barn (molonggo). Budgeting (mewala) is an essential part of farming activities that aims to mark land barriers and, at the same time, prevent the entry of pig pests or other animal disturbances. Another essential part is motasu, which is the activity of harvesting rice seeds, vegetables, and the like, which is generally carried out at the end of the dry season.

\subsection{Disaster Mitigation in Tolaki Community Cultivation System}

Traditional communities and the local people moving in Asera Sub-district have long practiced friendly living management with the environment [29]. They utilize natural resources based on societal values and norms that ensure the sustainability and sustainability of nature. Local cultural wisdom formed from moving farming activities is realized in patterns of action that are adaptive to the environment and have an essential contribution in preventing and reducing the risk of disasters [30]. There are several principles in the tradition of moving farms identified as having functions as mitigation of natural disasters, especially forest fire disasters, erosion, landslides, and floods. Below are some traditions in carrying farming activities (monda'u) containing education, avoiding natural disasters that have been practiced for generations. 


\subsubsection{Selection of Farm Locations (Monggiikii Ando'olo)}

The first stage in farming activities (monda'u) is choosing the land location to work on or mongiikii ando'olo. The land to work on farming activities is flat for easy access and avoids erosion and landslides. The soil located on the mountain's slopes and its sloping position is usually prone to avalanches [31]. Another consideration in land selection is soil fertility to avoid using fertilizers, especially artificial fertilizers containing chemicals. The chosen soil fertility often enables plants to grow without plowing to preserve the ground's intensity.

\subsubsection{Land Burning}

Burning (huтипu) is an activity that aims to clear the fields from the stems and branches of wood resulting from cut the roots and grass (mosalei) and logging (mombodoi/monduehi). Before burning, mekere is carried out to make a burning block in the form of a circular boundary that evacuates the fire not to cross to other areas. Mekere is a way of howling and modeling firefighting to control fires to prevent the risk of forest fires [32], [33]. The width of the bulkhead limit is about 3 (three) or 4 (four) meters. Besides being an entrance to arson control, it also inhibits the spread of fire to land or other areas. The results of mosalei, mombodoi, and mekere activities are dried first by staying a month or more for the combustion process.

Farmers have practical knowledge and experience in setting fire points before burning. One of the considerations is the direction of the wind when the combustion is about to take place. The perfect burn result depends heavily on the accuracy in the determination of the fire point. Burning is carried out simultaneously in the afternoon involving all the sailors. They are in the process of doing the maintenance until the burning procession is entirely complete [34]. The final part of this burning procession is to conduct an inspection and re-collect the trees and twig that have not burned entirely scorched (mo'enggai). Further re-burning of the wood's remains has not been wholly burned on the next occasion before planting.

In the process of land burning, it seems to be a planning function carried out collectively by the fielders [13]. Besides, there is also a group division to achieve maximum fire control. The agricultural community has implemented a hereditary controlled land burning system without resulting in widespread forest fires.

\subsubsection{Land Restoration and Plant Maintenance}

Disaster mitigation in farming activities in the Asera sub-district is also seen in land restoration and crop maintenance stages. The selection of wood and plant types used for fencing is based on consideration of the ability to withstand erosion in the event of heavy rains. Types of wood and plants are selected for fences based on traditionally ecological knowledge passed down through generations [35]. Before land burning, people carry out the fencing and select and sort the type of woodcut down used as a fence. In this way, the fielders no longer need to cut down the (new) wood trees in the forest to do the restoration so that the woods that are not the field's location remains sustainable.

Treatment of plants is carried out without fertilizers and pesticide toxins to minimize the negative impact on health. The farmers already have local knowledge of fertile soil and infertile soil. At the time of field location selection, soil fertility is one of the considerations. Thus, they no longer need to use fertilizer, either organic fertilizer or chemical fertilizer. This fact disputes some people who think that the farm system is moving, causing harm to fauna and plant species and soil fertility [36]. To avoid attacks on plant pests, the researchers agreed to plant seeds simultaneously. This is local knowledge sourced from experience and has been hereditary practiced. Although the production is not as much if using modern technology, it is considered safer and healthier.

\subsubsection{Planting Perishes before the Death of Land}

After the land deteriorated infertility due to repeated use, the farms left the farm site and moved to a new location. Before leaving the old ground (anahoma) people grow to perk crops such as teak, pine, and coconut as proof of ownership. In addition to proof of ownership, planting plants, or hard trees is one of the forest regeneration efforts after farming activities [37]. The concept of anahoma serves as a form of land conservation and restoration that impacts disaster risk reduction [38].

Anahoma, which materializes into a forest after being abandoned, is usually a former processed area of some local people who still come from one large family (relatives). Under the provisions of Tolaki's customary law, the anahoma can be re-worked by the concerned or grandchildren after nine years of abandonment. In addition to serving as an identification of ownership, anahoma is also intended to re-forest forests that have been felled for farming purposes. Replanting trees and leaving them for nine years is one form of disaster mitigation to avoid floods and landslides [39]. Applying the concept of anahoma to the Tolaki indigenous people's farm activity has a dual function and ownership identity, restoring soil fertility to be reprocessed [40]. Ultimately also make the function of the forest maintain the ecosystem and the balance of nature supported. 


\section{Conclusions and Suggestions}

The Tolaki people who live in Asera Sub-district have distinctive local wisdom as an adaptation strategy to the moving farming activities environment. This local wisdom is inseparable from the beliefs and customs taught and practiced through generations. With local knowledge, the local community can also anticipate and reduce the risk of disaster. Institutions of monda'u, which are loaded with disaster risk education, keep people afloat and live well. The tradition of farming, namely the values and norms of monda'u activities ranging from site selection to land clearing to crop storage, is loaded with mitigation against natural disasters, especially floods, landslides, and fires. Local knowledge of disaster mitigation is very important to be applied to environmental adaptation amidst the rise of profit-oriented mining businesses.

The number of natural disasters, such as floods and landslides lately, hints at the importance of digging back local wisdom that has been shown to maintain the balance of nature. The results of this study can contribute thought to the development of social sciences, especially the study of environmentally sound development. Integrating several traditional farming methods containing local knowledge in modern agricultural practice can minimize environmental damage as one source of floods and landslides. Disaster experience in local communities has sharpened the ability to identify disaster risks to improve early disasters warning.

This research is limited to disaster mitigation in anticipation and prevention of natural disasters in moving farming activities (monda'u). Hence, future research should identify disaster mitigation related to victims' handling when disasters have occurred and formulate disaster management policies at the regional and national levels.

\section{References}

[1] T. Okubo, "Traditional wisdom for disaster mitigation in history of Japanese Architectures and historic cities," J. Cult. Herit., vol. 20, pp. 715-724, 2016, doi: 10.1016/j.culher.2016.03.014.

[2] J. Widodo, "Urban Environment and Human Behaviour: Learning from History and Local Wisdom," Procedia - Soc. Behav. Sci., vol. 42, no. July 2010, pp. 6-11, 2012, doi: 10.1016/j.sbspro.2012.04.161.

[3] H. Azadi, D. C. Petrescu, R. M. Petrescu-Mag, and A. Ozunu, "Special issue: Environmental risk mitigation for sustainable land use development," Land use policy, vol. 95, no. January, p. 104488, 2020, doi: 10.1016/j.landusepol.2020.104488.

[4] K. Srividhya, A. Mohan, M. Tholkapiyan, and A. Arunraj, "Earth quake disaster mitigation (EQDM) through engineering design," Mater. Today Proc., vol. 22, no. xxxx, pp. 1074-1077, 2020, doi: 10.1016/j.matpr.2019.11.303.

[5] K. Scholten, P. S. Scott, and B. Fynes, "Mitigation processes - antecedents for building supply chain resilience," Supply Chain Manag., vol. 19, no. 2, pp. 211-228, 2014, doi: 10.1108/SCM-06-2013-0191.

[6] M. K. Lindell, "Disaster studies," Curr. Sociol., vol. 61, no. 5-6, pp. 797-825, 2013, doi: $10.1177 / 0011392113484456$.

[7] D. Kuang and K. H. Liao, "Learning from Floods: Linking flood experience and flood resilience," J. Environ. Manage., vol. 271, no. June, p. 111025, 2020, doi: 10.1016/j.jenvman.2020.111025.

[8] P. Segall, "Volcano deformation and eruption forecasting," Geol. Soc. Spec. Publ., vol. 380, no. 1, pp. 85-106, 2013, doi: 10.1144/SP380.4.

[9] F. Usman, K. Murakami, and E. B. Kurniawan, "Study on Reducing Tsunami Inundation Energy by the Modification of Topography based on Local Wisdom," Procedia Environ. Sci., vol. 20, pp. 642-650, 2014, doi: 10.1016/j.proenv.2014.03.077.

[10] O. Tsedendemberel, "The happy youth of a desperate country: The disconnect between Japan's malaise and its millennials, by Noritoshi Furuichi (Japan Publishing Industry Foundation for Culture, Japan, 2017)," Corvinus J. Sociol. Soc. Policy, vol. 10, no. 1, pp. 179-184, 2019, doi: 10.14267/cjssp.2019.1.11.

[11] G. P. Cuaton and Y. Su, "Local-indigenous knowledge on disaster risk reduction: Insights from the Mamanwa indigenous peoples in Basey, Samar after Typhoon Haiyan in the Philippines," Int. J. Disaster Risk Reduct., vol. 48, no. July 2019, p. 101596, 2020, doi: 10.1016/j.ijdrr.2020.101596.

[12] V. R. Vitasurya, "Local Wisdom for Sustainable Development of Rural Tourism, Case on Kalibiru and Lopati Village, Province of Daerah Istimewa Yogyakarta," Procedia Soc. Behav. Sci., vol. 216, no. October 2015, pp. 97-108, 2016, doi: 10.1016/j.sbspro.2015.12.014.

[13] L. C. Bresser-Pereira, "Reflecting on new developmentalism and classical developmentalism," Rev. Keynes. Econ., vol. 4, no. 3, pp. 351-352, 2016, doi: 10.4337/roke.2016.03.07. 
[14] S. Kakoty, "Ecology, sustainability and traditional wisdom," J. Clean. Prod., vol. 172, pp. 3215-3224, 2018, doi: 10.1016/j.jclepro.2017.11.036.

[15] E. Çolak and F. Sunar, "Evaluation of forest fire risk in the Mediterranean Turkish forests: A case study of Menderes region, Izmir," Int. J. Disaster Risk Reduct., vol. 45, no. July 2019, p. 101479 , 2020 , doi: 10.1016/j.ijdrr.2020.101479.

[16] J. H. Park, S. H. Park, and K. A. Kim, "Disaster management and land administration in South Korea: Earthquakes and the real estate market," Land use policy, vol. 85, no. May 2018, pp. 5262, 2019, doi: 10.1016/j.landusepol.2019.03.040.

[17] İ. Unay-Gailhard and Š. Bojnec, "Public support effect on natural disaster management: A case study of ice storms in forests in Slovenia," Land use policy, vol. 95, no. August 2018, p. 103811, 2020, doi: 10.1016/j.landusepol.2019.01.014.

[18] A. Schwann, "Ecological wisdom: Reclaiming the cultural landscape of the Okanagan Valley," J. Urban Manag., vol. 7, no. 3, pp. 172-180, 2018, doi: 10.1016/j.jum.2018.05.004.

[19] P. S. S. Lin and K. M. Chang, "Metamorphosis from local knowledge to involuted disaster knowledge for disaster governance in a landslide-prone tribal community in Taiwan," Int. J. Disaster Risk Reduct., vol. 42, no. xxxx, p. 101339, 2020, doi: 10.1016/j.ijdrr.2019.101339.

[20] Y. J. He, T. Chen, and L. Han, "An automatic monitoring method of slope deformation in open-pit mine based on bp neural network and gis technology," Int. J. Circuits, Syst. Signal Process., vol. 14, pp. 353-360, 2020, doi: 10.46300/9106.2020.14.48.

[21] E. Kingwell-Banham and D. Q. Fuller, "Shifting cultivators in South Asia: Expansion, marginalisation and specialisation over the long term," Quat. Int., vol. 249, pp. 84-95, 2012, doi: 10.1016/j.quaint.2011.05.025.

[22] I. Ruiz-Mallén and E. Corbera, "CommunityBased Conservation and Traditional Ecological Knowledge," Ecol. Soc., vol. 18, no. 4, p. 12, 2013.

[23] M. Gerichhausen, E. D. Berkhout, H. J. M. Hamers, and V. M. Manyong, "A quantitative framework to analyse cooperation between rural households," Agric. Syst., vol. 101, no. 3, pp. 173-185, 2009, doi: 10.1016/j.agsy.2009.05.005.

[24] P. M. Villa et al., "Intensification of shifting cultivation reduces forest resilience in the northern Amazon," For. Ecol. Manage., vol. 430, no. August, pp. 312-320, 2018, doi: 10.1016/j.foreco.2018.08.014

[25] C. J. Kilawe, O. Mertz, D. S. A. Silayo, T. Birch-Thomsen, and S. M. Maliondo, "Transformation of shifting cultivation: Extent, driving forces and impacts on livelihoods in Tanzania," Appl. Geogr., vol. 94, no. July 2017, pp. 84-94, 2018, doi: 10.1016/j.apgeog.2018.03.002.

[26] S. Martire, V. Castellani, and S. Sala, "Carrying capacity assessment of forest resources: Enhancing environmental sustainability in energy production at local scale," Resour. Conserv. Recycl., vol. 94, pp. 11-20, 2015, doi: 10.1016/j.resconrec.2014.11.002.

[27] D. F. C. de Andrade, A. R. Ruschel, G. Schwartz, J. O. P. de Carvalho, S. Humphries, and J. R. V. Gama, "Forest resilience to fire in eastern Amazon depends on the intensity of pre-fire disturbance," For. Ecol. Manage., vol. 472, no. November 2019, p. 118258, 2020, doi: 10.1016/j.foreco.2020.118258.

[28] A. Schneibel et al., "Assessment of spatiotemporal changes of smallholder cultivation patterns in the Angolan Miombo belt using segmentation of Landsat time series," Remote Sens. Environ., vol. 195, pp. 118-129, 2017, doi: 10.1016/j.rse.2017.04.012.

[29] D. Roos, C. Caminero Saldaña, B. Arroyo, F. Mougeot, J. J. Luque-Larena, and X. Lambin, "Unintentional effects of environmentallyfriendly farming practices: Arising conflicts between zero-tillage and a crop pest, the common vole (Microtus arvalis)," Agric. Ecosyst. Environ., vol. 272, no. August 2018, pp. $\quad 105-113, \quad 2019, \quad$ doi: 10.1016/j.agee.2018.11.013.

[30] E. Gómez-Baggethun, E. Corbera, and V. Reyes-García, "Traditional ecological knowledge and global environmental change: Research findings and policy implications," Ecol. Soc., vol. 18, no. 4, 2013, doi: 10.5751/ES-06288-180472.

[31] X. li Chen, C. guo Liu, M. ming Wang, and Q. Zhou, "Causes of unusual distribution of coseismic landslides triggered by the $\mathrm{Mw} 6.1$ 2014 Ludian, Yunnan, China earthquake," $J$. Asian Earth Sci., vol. 159, no. March, pp. 1723, 2018, doi: 10.1016/j.jseaes.2018.03.010.

[32] A. Dhall, A. Dhasade, A. Nalwade, M. R. Mohan, and V. Kulkarni, "A survey on systematic approaches in managing forest 
fires," Appl. Geogr., vol. 121, no. June, p. 102266, 2020, doi: 10.1016/j.apgeog.2020.102266.

[33] H. G. Zhang, Z. H. Liang, H. J. Liu, R. Wang, and Y. A. Liu, "A benchmark dataset for ensemble framework by using nature inspired algorithms for the early-stage forest fire rescue," Data Br., vol. 31, p. 105686, 2020, doi: 10.1016/j.dib.2020.105686.

[34] E. D. Nopembereni, S. Sugiyanto, K. Sukesi, and Y. Yuliati, "Local Wisdom in Shifting Cultivation Management of Dayak Ngaju Community, Central Kalimantan," $J$. Socioecon. Dev., vol. 2, no. 1, p. 38, 2019, doi: 10.31328/jsed.v2i1.939.

[35] J. F. Martin, E. D. Roy, S. A. W. Diemont, and B. G. Ferguson, "Traditional Ecological Knowledge (TEK): Ideas, inspiration, and designs for ecological engineering," Ecol. Eng., vol. 36, no. 7, pp. 839-849, 2010, doi: 10.1016/j.ecoleng.2010.04.001.

[36] T. M. Magalhães and F. P. S. Mamugy, "Fine root biomass and soil properties following the conversion of miombo woodlands to shifting cultivation lands," Catena, vol. 194, no. May, p. 104693, 2020, doi: 10.1016/j.catena.2020.104693.

[37] K. Teegalapalli and A. Datta, "Field to a forest: Patterns of forest recovery following shifting cultivation in the Eastern Himalaya," For. Ecol. Manage., vol. 364, pp. 173-182, 2016, doi: 10.1016/j.foreco.2016.01.006.

[38] J. A. Klein et al., "An integrated community and ecosystem-based approach to disaster risk reduction in mountain systems," Environ. Sci. Policy, vol. 94, no. November 2018, pp. 143152, 2019, doi: 10.1016/j.envsci.2018.12.034.

[39] M. M. Sarabia et al., "The challenges of impact evaluation: Attempting to measure the effectiveness of community-based disaster risk management," Int. J. Disaster Risk Reduct., vol. 49, 2020, doi: 10.1016/j.ijdrr.2020.101732.

[40] A. Höhn and K. Neumann, "Shifting cultivation and the development of a cultural landscape during the Iron Age (0-1500 AD) in the northern Sahel of Burkina Faso, West Africa: Insights from archaeological charcoal," Quat. Int., vol. 249, pp. 72-83, 2012, doi: 10.1016/j.quaint.2011.04.012.

\section{Contribution of individual authors to the creation of a scientific article (ghostwriting policy)}

Jamaluddin Hos wrote a draft paper, sought references, sites paper, and formulated general conclusions

Sarpin and Suharty Roslan completed the data, refined the methodology, improved the language Ratna Supiyah and Hasniah sharpened the analysis, improved the structure of the study, and formulated the abstract

\section{Creative Commons Attribution License 4.0 (Attribution 4.0 International, CC BY 4.0)}

This article is published under the terms of the Creative Commons Attribution License 4.0 https://creativecommons.org/licenses/by/4.0/deed.en_ US 